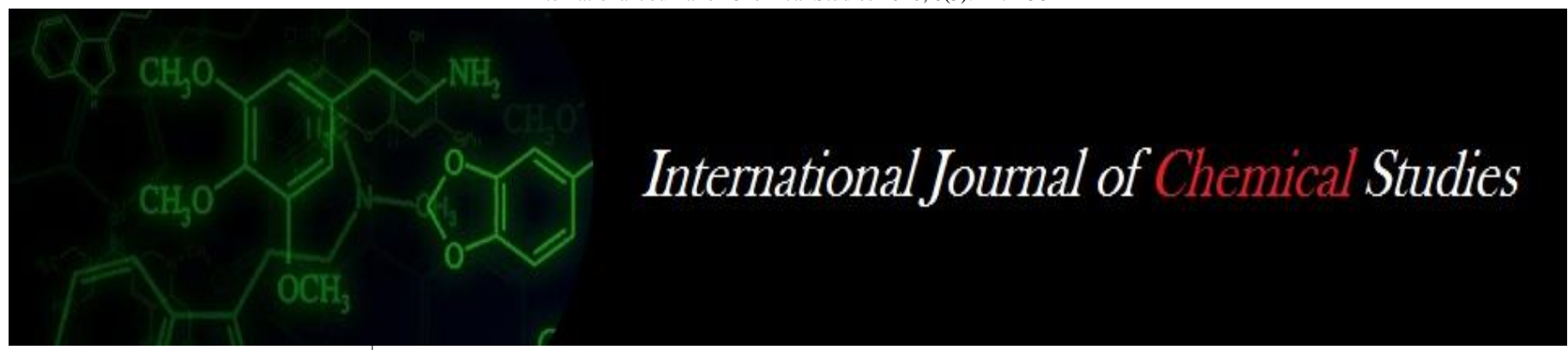

P-ISSN: 2349-8528

E-ISSN: 2321-4902

www.chemijournal.com

IJCS 2020; 8(5): 247-258

(C) 2020 IJCS

Received: 20-06-2020

Accepted: 08-08-2020

\section{NK Toorray}

Assistant Professor, College of

Agriculture and Research

Station, IGKV, Marra, Durg,

Chhattisgarh, India

PK Tiwari

Principal Scientist, CoA, IGKV,

Raipur, Chhattisgarh, India

\section{AS Kotasthane}

HOD, Department of Plant

Pathology, CoA, IGKV, Raipur,

Chhattisgarh, India

\section{OP Parganiha}

Assistant Professor, College of

Agriculture and Research

Station, IGKV, Marra, Durg,

Chhattisgarh, India
Corresponding Author: NK Toorray

Assistant Professor, College of

Agriculture and Research

Station, IGKV, Marra, Durg,

Chhattisgarh, India

\section{Evaluation of aggressiveness of different isolates of Rizoctonia solani causing sheath blight disease of rice collected from different districts of Chhattisgarh}

\author{
NK Toorray, PK Tiwari, AS Kotasthane and OP Parganiha
}

DOI: https://doi.org/10.22271/chemi.2020.v8.i5d.10304

\begin{abstract}
Awareness of the pathogenicity and aggressiveness nature of each pathogenic microbe is necessary not only to understand the expression of symptoms, but also contribute to the sheath blight disease control programme. The intensive survey of sheath blight infected farmers fields during the kharif 2015-16 at forty one locations of fifteen districts of Chhattisgarh plane were carried out and the disease samples were collected at maximum tillering stage of rice. Sheath blight and banded blight symptoms were examined for detail study. Naturally infected plant samples of sheath blight have been obtained from the fields in the laboratory for isolation and purification of sheath blight fungus. The pathogen was isolated on PDA and the subcultures were purified using a single hyphal tip cutting method and kept on PDA at $28 \pm 2{ }^{\circ} \mathrm{C}$. Samples infected with the sheath blight disease of paddy were collected from different districts of Chhattisgarh for systematic study of sheath blight symptoms in rice. The total number of fiftyeight isolates were confirmed by the proof of the Koch postulates and classified in the category as weakly aggressive, moderately aggressive, aggressive and highly aggressive. The seven isolates were recorded as highly aggressive and the maximum PDI 98.15 was shown by the isolate no. RS57.
\end{abstract}

Keywords: Sheath blight, rice, aggressiveness, 58 isolates, symptoms develpment, lesion length, PDI, disease control

\section{Introduction}

Rice (Oryzae sativa L.) is the staple food crop of over half of the world's population, and is also widely cultivated across the world, making it possibly the most valuable plant on earth (Shimamoto, 1995; Goff, 1999) ${ }^{[29,9]}$. It provides 20 percent of the world's supply of dietary energy followed by maize and wheat. Rice grows in at least 114 countries and more than 50 have a capacity of 100,000 tons or more per year. The production of rice to be adept by 2020 is $128 \mathrm{Mt}$. to feed the growing population in India. This crop also suffers due to number of diseases accounting for severe losses. Of the several factors known to destabilize rice yields, pests and diseases account for 30-40 percent crop losses. Most parts of the country regularly encounter complete crop failure due to epidemics of pests and diseases. In Chhattisgarh, rice production is comparatively smaller than the national average production. A lot of fungal, bacterial, nematode, and viral diseases are attacked on rice. Serious incidences of diseases such as blast, sheath blight and bacterial blight have been reported from rice growing areas in Chhattisgarh regions. Sheath blight is one of India's widespread and harmful rice diseases. Rice sheath blight disease is causing significant loss, particularly in areas where high yielding varieties are cultivated. Rhizoctonia solani (Perfect stage-Thanatephorus cucumeris) which causes rice sheath blight in both soil and water borne. Miyake (1910) ${ }^{[19]}$ stated that the sheath blight disease was first reported from Japan. Subsequently this disease was recorded from various global rice-growing regions, and particularly from major rice-growing countries. The presence of sheath blight disease in rice from several parts of India and beyond has been confirmed by workers of different parts of India. Butler made reference to the Indian disease as early as 1918. The presence of this disease has been confirmed by Andhra Pradesh, Assam, Jammu and Cashmir, Kerala, Tamil Nadu (Anonymous, 1971) ${ }^{[4]}$, Orissa and West Bengal (Das, 1970) ${ }^{[6]}$, Madhya Pradesh (Anonymous, 1975; Verma et al., 1979) ${ }^{[2,34]}$. 
The initial symptoms usually develop as lesions on sheaths of lower leaves close to the waterline, when plants are in the growth stage of late tillering or nearly internode elongation typically these lesions develop as oval to elliptical, green gray, just below the leaf collar, water soaked spots about 1/4 inch wide and $1 / 2$ to $1 / 4$ inch in length. The disease has been named as "sheath blight" because of primary infection on leaf sheath. High doses of nitrogen fertilizers, intensive cultivation of modern high yielding veriety, early maturation, high tillering rice varieties with double farming leads to increased severity of diseases, eventually yield losses of about $50 \%$ were recorded in Japan, Vietnam, South Korea, Taiwan, China, USA and India (Anonymous, 1988) ${ }^{[3]}$. Several workers reported, yield loss ranging from 20-50\% in highly susceptible cultivars (Lee and Rush, 1983; Rajan and Naidu, 1986; Mizuta, 1956; and Hori, 1969) ${ }^{[16,25,20,11]}$. Ou (1972) ${ }^{[21]}$ also reported a grain yield loss of 25 per cent due to sheath blight. The disease is common in areas where there is high temperature $\left(30 \pm 32{ }^{\circ} \mathrm{C}\right)$ and relative humidity (> 95 percent) and in intensive cultivation areas.

Awareness of the pathogenicity and aggressiveness nature of each pathogenic microbe is necessary not only to understand the expression of symptoms, but also contribute to the sheath blight disease control programme. Similar symptoms on rice sheaths are caused by a variety of fungal species and often difficult to distinguish by visual observation (Matsumoto 2003) ${ }^{[18]}$. Several researchers have observed differences in the length of the lesion among different isolates of Rhizoctonia solani (Sneh et al. 1996; Vidhyasekaran et al. 1997; Chaijuckam et al. 2010) ${ }^{[31,35,5]}$. However, the soilborne nature of pathogen and the sustained persistence of its sclerotia complicate the chemical regulation of this disease. Saxena (1997) [26] reported that three characters were significant. In the first group isolates can cause different types of diseases and symptoms, in the second group the state of aggressiveness can differ and in the third group the host between the isolates can shift from limited to very far. Sriram et al. (1997) ${ }^{[32]}$ investigated pathogenic variations in seven isolates of the $R$. solani rice sheath rot that had been collected in seven large rice growing areas in southern India since 1994. The isolate was collected from Thiruvanantapuram (RS7) and was highly aggressive.

\section{Materials and method Symptoms of sheath blight disease}

The initial signs typically develop as lesions on sheaths of lower leaves near the waterline while plants are in the growth stage of late tillering or nearly internodal elongation. These lesions usually grow as oval to elliptical, green gray, just below the leaf collar, water soaked spots about $1 / 4$ inch wide and $1 / 2$ to $1 / 4$ inch long. The disease has been named as "sheath blight" because of primary infection on leaf sheath. The fungus attack the crop from tillering to heading stage and leaf blade symptoms also observed. The presence of several large lesions on leaf sheath causes death of whole leaf and in several causes all the leaves of a plant blighted. The infection spreads to inner sheath resulting death of entire plant. These types of symptoms are popularly called as banded blight. In the banded blight phase, the flag leaf and panicle infection prevented the normal emergence and expansion of the ears and caused poor filling of the grains.

\section{Collection of disease samples}

The disease samples were collected from naturally infected rice plants from farmers field of district i.e. Rajnandgaon, Bemetara, Mahasamund, Balod, Raipur, Dhamtari, Kabirdham, Gariyaband, Durg, Kanker, Narainpur, Raigarh, Jaspur, Korea, Korba of Chhattisgarh during kharif 20152016 at maximum tillereing stage of rice crop. The detail about the survey is presented under the table given:
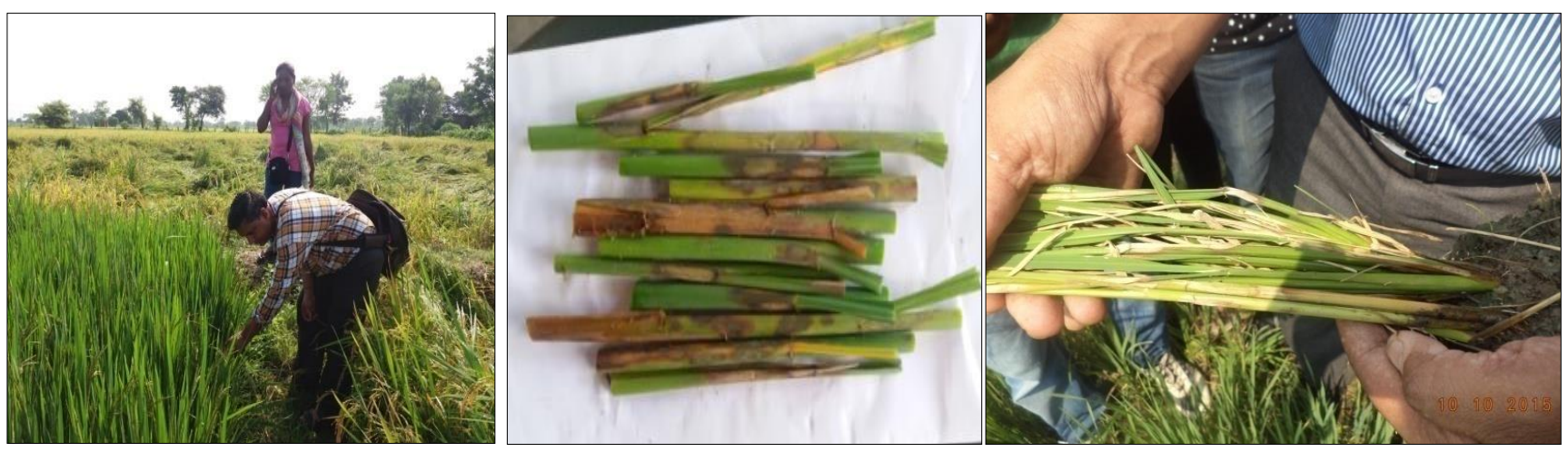

Fig 1.1: Collection and isolation of sheath blight disease samples

\section{Isolation of the pathogen}

The disease affected samples obtained from the different localities were separately washed thoroughly with tap water. Small portion of the infected parts containing healthy as well as diseased tissues were cut in to $0.5 \mathrm{~cm}$ pieces with the help of sterilized scalpel blade. These pieces were then surface sterilized with 1 percent sodium hypochlorite solution for 1 minute with 3 subsequent changes in sterilized water to remove traces of the chemical. The pieces were then transferred aseptically to petri dishes containing sterilized Potato Dextrose Agar (PDA) and incubated at $28 \pm 2^{\circ} \mathrm{C}$ under BOD incubator. The petri dishes were examined at regular time intervals for fungal growth radiating from the infected pieces and the 58 isolates were isolated. 

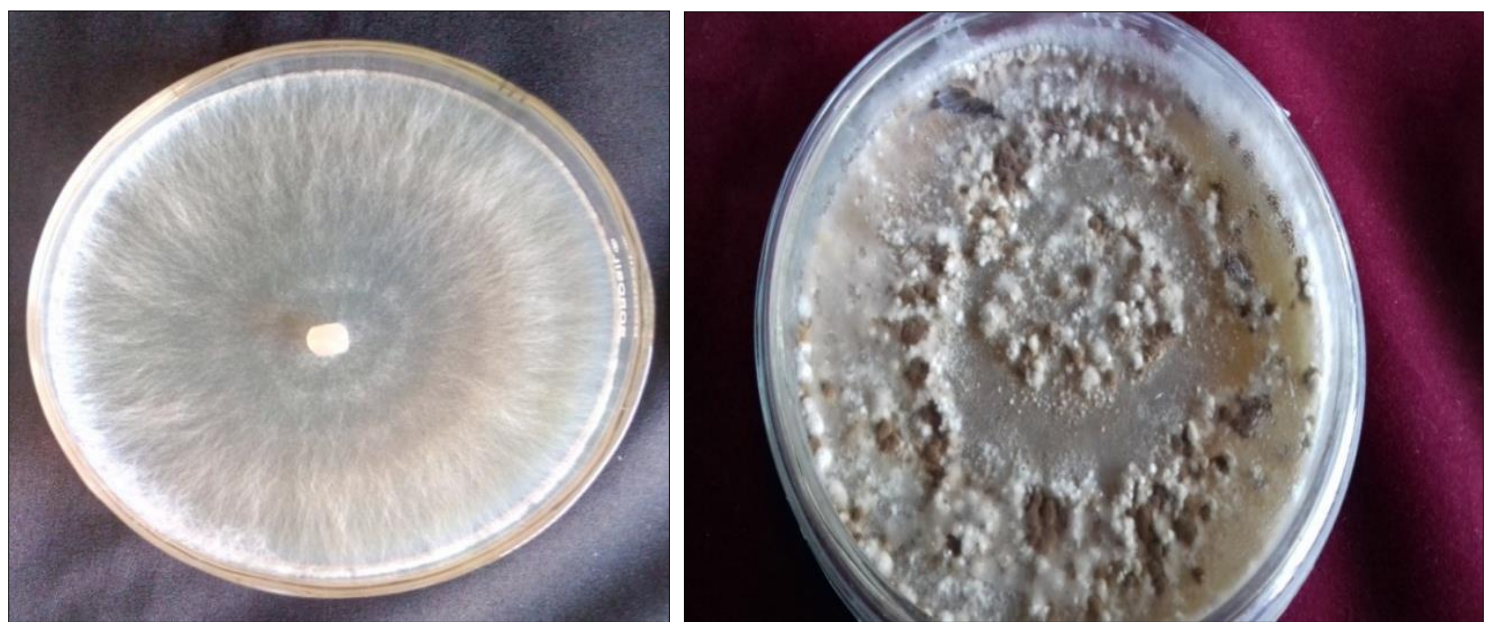

Fig. 1.2: Plate No. 1.1 and 1.2 Pure culture of $R$. solani

\section{Purification}

After supplementing with a pinch of streptomycin sulphate, about $20 \mathrm{ml}$ of PDA medium was poured into each petri-dish to prevent bacterial contamination. One $8 \mathrm{~mm}$ mycelial disc from a freshly isolated culture was transferred aseptically to the solidified PDA in each petri dish by hyphal tip cut method. The dishes were incubated at $28 \pm 2^{\circ} \mathrm{C}$ in BOD incubator. Adequate numbers of sub culture transformation were separately made for further purification and all the collected 58 isolates were purified and confirmed to the current species concept of $R$. solani (Parmeter and Whitney, $1970)^{[22]}$ and maintained under deep freezer at $-20^{\circ} \mathrm{C}$.

\section{Mass multiplication of inoculums}

Stems of 35-40 days old rice plants were cut in to pieces of about $2 \mathrm{~cm}$ size and filled in to $500 \mathrm{ml}$ Erlenmeyer flasks up to one third. Flasks were autoclaved at 15 pound per square inch for 30 minutes. Mycelial discs of $5 \mathrm{~mm}$ diameter cut from the margin of $48 \mathrm{hrs}$ old culture of the pathogen were inoculated into the flask and incubated at $28 \pm 2^{\circ} \mathrm{C}$ up to fifteen days for full growth of fungus and sclerotia formation. For artificial inoculation, rice plants at maximum tillering stage were taken for inoculation.

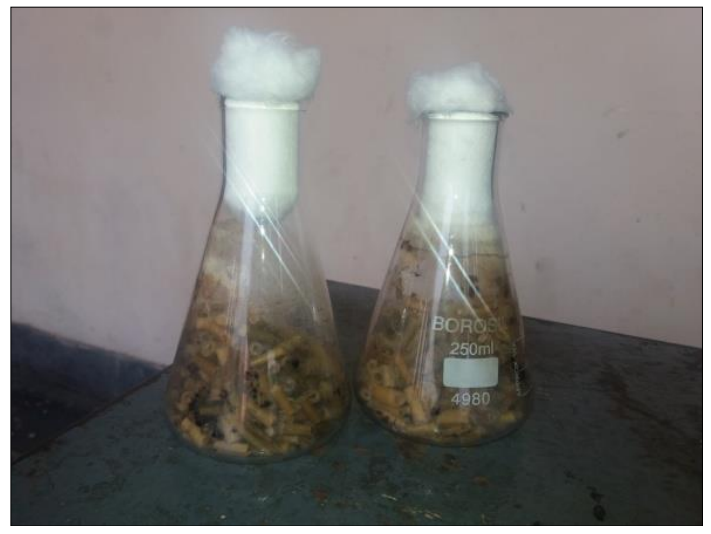

Fig 1.3: Mass multiplication of $R$. solani

\section{Inoculation}

Rice stem bits (Rhizoctonia solani mycelium profusely grown) and sclerotia from 7-9 days old culture were used for inoculation of the rice plants at the maximum tillering stage. The primary tillers of each hill were tagged and gently inoculated by punching and pushing into the sheath a single sclerotium or rice stem bit just $1 \frac{1 / 2}{2}$ to $21 / 2 \mathrm{~cm}$ above the water surface level as per the sheath location. After 12 hours plants were examined for symptoms. The disease severity (lesion length) was assessed 21 days after inoculation.
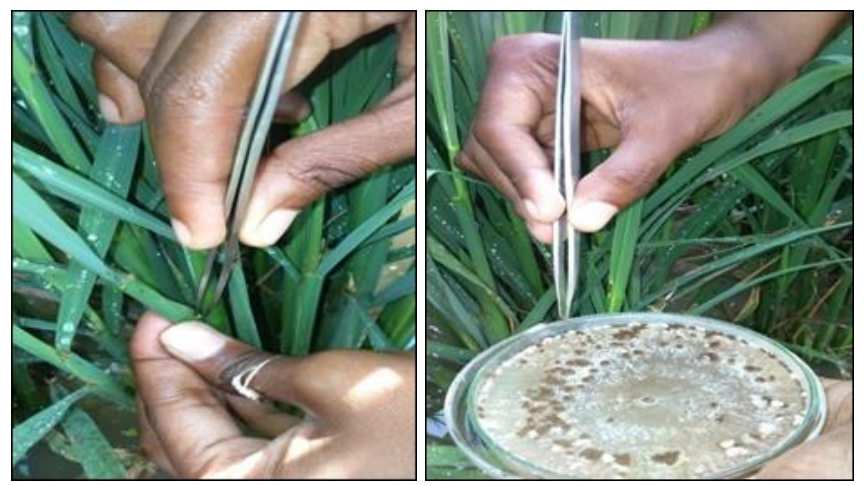

Fig 1.4: Artificial Inoculation

\section{Evaluation of aggressiveness of different isolates of $R$. solani}

This experiment was conducted under pot condition in completely randomyzed design (CRD) with four replications during kharif 2016 and 2017. Artificial inoculation was done at the maximum rice tillering stage using mycelial block of 5day-old culture. To study the aggressiveness, sclerotia and stem bits were inoculated in to rice plants for development of symptom, mycelial growth and sclerotial production to record aggressiveness of Rhizoctonia solani isolates. Observations for disease initiation and lesion length were recorded regularly at $24 \mathrm{~h}$ interval after inoculation upto 3 weeks of the study period in kharif season. All the collected isolates were measured for aggressiveness based on the disease symptoms development, 24 hours incubation period after inoculation up to three weeks. Obsrevation on the Lesion lenght, Relative lesion height, Percent disease severity and Percent Disease Index was recorded and also calculated. The control plants were not inoculated with sclerotia and they did not show any symptom.

\section{Incubation period}

The experiment was conducted under pot condition to observe the incubation period of the different isolates of $R$. solani inoculated on rice cultivar Swarna. The data were recorded after $12 \mathrm{~h}$ of inoculation.

\section{Lesion height}

The lesion height was recorded 21 days after inoculation of different isolates of $R$. solani on the rice cultivar. 


\section{Plant height}

The plant height was recorded 75 days after transplanting (DAT).

\section{Relative Lesion Height}

The Relative Lesion Height (RLH) was recorded 21 days after inoculation (DAI) of different isolates of $R$. solani on the rice cultivar. The relative lesion height $(\mathrm{cm})$ in each tiller was calculated by using the formula given by Sharma et al. (2013) [27]:
RLH = Maximum height at which lesion appear/Plant height $\mathrm{x} 100$.

\section{Disease severity}

Each plot was observed in number of infected tiller and each tiller was observed plant height and symptoms length of sheath blight of rice. The disease development was recorded and disease severity was calculated as standard evaluation system (SES), IRRI (2014) ${ }^{[12]}$. Observations were recorded 21 days after inoculation and graded as per 0-9 SES scale. The sheath blight scale was as follows:

Table 1.1: Standard evaluation system (SES), IRRI (2014) ${ }^{[12]}$

\begin{tabular}{|c|c|c|}
\hline Disease rating scale & Response & Description \\
\hline 0 & Immune & No Infection \\
\hline 1 & Highly Resistant & Vertical spread of the lesions up to 20\% of plant height \\
\hline 3 & Resistant & Vertical spread of the lesions up to 21-30\% of plant height \\
\hline 5 & Moderately Resistant & Vertical spread of the lesions up to 31-45\% of plant height \\
\hline 7 & Susceptible & Vertical spread of the lesions up to 46-65\% of plant height \\
\hline 9 & Highly Susceptible & Vertical spread of the lesions up to 66-100\% of plant height \\
\hline
\end{tabular}

The disease severity was calculated as:

Disease severity = - $\begin{gathered}\text { Total lesion length } \\ \text { Total length of sheath }\end{gathered}$

\section{Percent Disease Index (PDI)}

PDI was calculated 21 days after inoculation by the formula given by Wheeler.

$$
\text { PDI }=\frac{(\text { Sum of all ratings } \times 100)}{(\text { Total no. of observations } \times \text { Maximum rating scale })}
$$

\section{Categorization of Aggressiveness}

Aggressiveness of all the isolates of $R$. solani was categorized into 4 classes i.e. Weakly Aggressive (WA), Moderately Aggressive (MA), Aggressive (A) and Highly Aggressive (HA). PDI\% (2-21)=WA; PDI\% (22-43)=MA; PDI\% 44-
$65 \%=\mathrm{A} ; \mathrm{PDI} \%(66-87)=\mathrm{HA}$.

\section{Results and discussion}

The extensive survey was done (presented in table 1.3) and the diseased samples were collected from 58 farmer fields from 41 locations of (Mohad, Jungleswer, Somni, Mokhala, Dewada, Kaketara, Ratepayali, Ghumka, Odiya, Haldi, Chhichhanpahri, Tolagaon, Kanhe, Dharmapur, Surgi, Mohbhatta, Mahasamund, Saloni, Khadgaon, Sanesara, Gathala, Kumarda, Muretitola, Bhathasakri, Kutelikhurd, Jogidalli, Matri, Hirapur, Dhamtari, Surajpura, Nagdha, Singhola, Kirwai, Borsi, Pakhanjur, Narainpur, Lailunga, Jaspur, Korea, Utai and Pali) situated in fifteen districts i.e. Rajnandgaon, Bemetara, Mahasamund, Balod, Raipur, Dhamtari, Kabirdham, Gariyaband, Durg, Kanker, Narainpur, Raigarh, Jaspur, Korea, Korba of Chhattisgarh during kharif 2015-16 at maximum tillereing stage of rice crop under natural conditions.

Table 1.2: Survey and collection of $R$. solani isolates collected from different locations of Chhattisgarh in kharif year 2015-16 at maximum tillering stage of rice.

\begin{tabular}{|c|c|c|c|c|c|c|c|}
\hline S. No & Village/location & Block & District & Cropping pattern & Variety & Name of the Isolates & Pathogenic \\
\hline 1 & Mohad & Rajnandgaon & Rajnandgaon & Rice-Wheat- Fellow & Swarna & RS1 & + \\
\hline 2 & Mohad & Rajnandgaon & Rajnandgaon & Rice-Fellow- Rice & Swarna & RS2 & + \\
\hline 3 & Mohad & Rajnandgaon & Rajnandgaon & Rice- Wheat-Rice & Swarna & RS3 & + \\
\hline 4 & Jungleswer & Rajnandgaon & Rajnandgaon & Rice-Fellow- Fellow & Swarna & RS4 & + \\
\hline 5 & Jungleswer & Rajnandgaon & Rajnandgaon & Rice-Fellow- Fellow & Swarna & RS5 & + \\
\hline 6 & Jungleswer & Rajnandgaon & Rajnandgaon & Rice-Wheat- Fellow & Swarna & RS6 & + \\
\hline 7 & Jungleswer & Rajnandgaon & Rajnandgaon & Rice-Fellow- Fellow & Mahamaya & RS7 & + \\
\hline 8 & Somni & Rajnandgaon & Rajnandgaon & Rice-Fellow- Fellow & Swarna & RS8 & + \\
\hline 9 & Mokhala & Rajnandgaon & Rajnandgaon & Rice-Fellow- Fellow & Swarna & RS9 & + \\
\hline 10 & Dewada & Rajnandgaon & Rajnandgaon & Rice-Gram- Fellow & Swarna & RS10 & + \\
\hline 11 & Kaketara & Rajnandgaon & Rajnandgaon & Rice-Fellow- Fellow & Swarna & RS11 & + \\
\hline 12 & Ratepayali & Dongergaon & Rajnandgaon & Rice-Fellow- Fellow & Swarna & RS12 & + \\
\hline 13 & Ghumka & Rajnandgaon & Rajnandgaon & Rice-Fellow- Rice & Swarna & RS13 & + \\
\hline 14 & Odiya & Chhuikhadan & Rajnandgaon & Rice-Gram- Fellow & Swarna & RS14 & + \\
\hline 15 & Odiya & Chhuikhadan & Rajnandgaon & Rice-Fellow- Rice & Swarna & RS15 & + \\
\hline 16 & Haldi & Rajnandgaon & Rajnandgaon & Rice-Fellow- Fellow & Swarna & RS16 & + \\
\hline 17 & Haldi & Rajnandgaon & Rajnandgaon & Rice-Gram- Fellow & Swarna & RS17 & + \\
\hline 18 & Haldi & Rajnandgaon & Rajnandgaon & Rice & Swarna & RS18 & + \\
\hline 19 & Haldi & Rajnandgaon & Rajnandgaon & Rice-Fellow- Rice & Swarna & RS19 & + \\
\hline 20 & Chhichhanpahri & Ambagarh-chowki & Rajnandgaon & Rice-Fellow- Fellow & Swarna & RS20 & + \\
\hline 21 & Tolagaon & Khairagarh & Rajnandgaon & Rice-Wheat- Fellow & Swarna & RS21 & + \\
\hline 22 & Kanhe & Ambagarh-chowki & Rajnandgaon & Rice-Fellow- Fellow & Swarna & RS22 & + \\
\hline 23 & Dharmapur & Khairagarh & Rajnandgaon & Rice-Fellow- Fellow & Swarna & RS23 & + \\
\hline
\end{tabular}




\begin{tabular}{|c|c|c|c|c|c|c|c|}
\hline 24 & Surgi & Rajnandgaon & Rajnandgaon & Rice-Fellow- Rice & Swarna & RS24 & + \\
\hline 25 & Surgi & Rajnandgaon & Rajnandgaon & Rice-Wheat- Fellow & Swarna & RS25 & + \\
\hline 26 & Mohbhatta & Berla & Bemetara & Rice-Fellow- Fellow & Swarna & RS26 & + \\
\hline 27 & Mahasamund & Mahasamund & Mahasamund & Rice & Swarna & RS27 & + \\
\hline 28 & Saloni & Rajnandgaon & Rajnandgaon & Rice-Gram- Fellow & Swarna & RS28 & + \\
\hline 29 & Saloni & Rajnandgaon & Rajnandgaon & Rice-Fellow- Fellow & Mahamaya & RS29 & + \\
\hline 30 & Saloni & Rajnandgaon & Rajnandgaon & Rice-Fellow- Rice & Swarna & RS30 & + \\
\hline 31 & Khadgaon & Manpur & Rajnandgaon & Rice-Fellow- Fellow & Mahamaya & RS31 & + \\
\hline 32 & Khadgaon & Manpur & Rajnandgaon & Rice-Fellow- Fellow & Swarna & RS32 & + \\
\hline 33 & Sanesara & Dongergaon & Rajnandgaon & Rice-Fellow- Fellow & Swarna & RS 33 & + \\
\hline 34 & Gathala & Rajnandgaon & Rajnandgaon & Rice-Wheat- Fellow & Mahamaya & RS 34 & + \\
\hline 35 & Kumarda & Dongergaon & Rajnandgaon & Rice-Gram- Fellow & Swarna & RS 35 & + \\
\hline 36 & Muretitola & Ambagarh-chowki & Rajnandgaon & Rice-Fellow- Rice & Swarna & RS 36 & + \\
\hline 37 & Bhathasakri & Saja & Bemetara & Rice-Fellow- Fellow & Swarna & RS 37 & + \\
\hline 38 & Kutelikhurd & Chhuikhadan & Rajnandgaon & Rice-Fellow- Fellow & Swarna & RS 38 & + \\
\hline 39 & Jogidalli & Rajnandgaon & Rajnandgaon & Rice-Fellow- Rice & Swarna & RS 39 & + \\
\hline 40 & Matri & Dondilohara & Balod & Rice-Fellow- Fellow & Swarna & RS 40 & + \\
\hline 41 & Hirapur & Dharsiwa & Raipur & Rice-Fellow- Fellow & Swarna & RS 41 & + \\
\hline 42 & Dhamtari & Dhamtari & Dhamtari & Rice-Fellow-Rice & Swarna & RS 42 & + \\
\hline 43 & Surajpura & Kawardha & Kabirdham & Rice-Fellow- Fellow & Swarna & RS 43 & + \\
\hline 44 & Nagdha & Nawagarh & Bemetara & Rice-Fellow- Fellow & Swarna & RS 44 & + \\
\hline 45 & Singhola & Khairagarh & Rajnandgaon & Rice-Gram- Fellow & Swarna & RS 45 & + \\
\hline 46 & Singhola & Khairagarh & Rajnandgaon & Rice-Fellow- Rice & Mahamaya & RS 46 & + \\
\hline 47 & Singhola & Khairagarh & Rajnandgaon & Rice-Wheat- Fellow & Swarna & RS 47 & + \\
\hline 48 & Kirwai & Fingeshwer & Gariyaband & Rice-Fellow- Fellow & Swarna & RS 48 & + \\
\hline 49 & Borsi & Durg & Durg & Rice-Wheat- Fellow & Swarna & RS 49 & + \\
\hline 50 & Pakhanjur & Kanker & Kanker & Rice-gram- Fellow & Swarna & RS 50 & + \\
\hline 51 & Narainpur & Narainpur & Narainpur & Rice-Fellow- Fellow & Swarna & RS 51 & + \\
\hline 52 & Lailunga & Raigarh & Raigarh & Rice-Fellow- Fellow & Swarna & RS 52 & + \\
\hline 53 & Jaspur & Jaspur & Jaspur & Rice-Fellow- Rice & Swarna & RS 53 & + \\
\hline 54 & Korea & Korea & Korea & Rice-Gramm- Rice & Swarna & RS 54 & + \\
\hline 55 & Utai & Durg & Durg & Rice-Fellow- Fellow & Swarna & RS 55 & + \\
\hline 56 & Pali & Katghora & Korba & Rice-Fellow- Rice & Swarna & RS 56 & + \\
\hline 57 & Kirwai & Fingeshwer & Gariyaband & Rice-Fellow- Rice & Mahamaya & RS 57 & + \\
\hline 58 & Kirwai & Fingeshwer & Gariyaband & Rice-Gram- Fellow & Swarna & RS 58 & + \\
\hline
\end{tabular}

Related results in the agreement with Swain et al. (2005) ${ }^{[33]}$, Xiao et al. (2008) ${ }^{[36]}$ and Prasad, V.R. (2014) ${ }^{[24]}$ who surveyed and collected the samples of sheath blight disease at maximum rice tillering stage.

\section{Isolation and purification of pathogen}

In the present study isolates were assigned code numbers such as RS1, where "RS" nemed Rhizoctonia solani and "1" denote the serial number of the isolate. Similarly, the other fifty-eight isolates were also referred to as RS1, RS2, RS3, RS4, RS5, RS6, RS7, RS8, RS9, RS10, RS11, RS12, RS13, RS14, RS15, RS16, RS17, RS18, RS19, RS20, RS21, RS22, RS23, RS24, RS25, RS26, RS27, RS28, RS29, RS30, RS31, RS32, RS33, RS34, RS35, RS36, RS37, RS38, RS39, RS40, RS41, RS42, RS43, RS44, RS45, RS46, RS47, RS48, RS49, RS50, RS51, RS52, RS53, RS54, RS55, RS56, RS57, RS58 were listed in Table No. 4.1. The sheath blight causing the $R$. solani pathogen was isolated and purified by a single hyphal tip / single sclerotial method. Cultures were kept in test tubes on sterile PDA slants maintained in $4^{\circ} \mathrm{C}$ to further investigate the variability. Similar results for isolation, purification and identification have been reported by Parmeter and Whitney $(1970)^{[22]}$.

\section{Systematic classification}

The causative agent of sheath blight, now commonly known as $R$. solani Kühn, and Thanatephorus cucumeris (Frank) Donk, a teleomorph (perfect stage). The teleomorph of the pathogen Thanatephorus cucumeris belongs to the family of the Ceratobasidiaceae of the order Tulasnellales in the form class Hymenomycetes, subclass Holobasidiomycetidae of the class Basidiomycetes. The anamorph $R$. solani comes under the class Deuteromycotina, form class Deutromycetes and order Aganomycetales (Dasgupta, 1992) ${ }^{[7]}$.

\section{Identification of the test fungus}

The isolated fungus was then identified based on the following morphological properties. $R$. solani does not form vegetative spores and is present as a mycelium and sclerotia. The isolate had typical characteristics of $R$. solani: (I) It creates a shade of brown hyphae. (II) Branches at right angles beside the distal septum of the cell in young hyphae. (III) formation of a septum in the branch beside the point of origin, (IV) narrowing at the branch point, dolipore septum, (V) moniloid cells, (VI) undifferentiated sclerotia and (VII) absence of rhizomorphs (VIII) clamp connection absent. Undifferentiated Sclerotia, aggregations of thick-walled cells, small (1-4 mm diameter) irregularly shaped brown to black structures (Guttierez et al. 1997) ${ }^{[10]}$. A similar result in identification was reported by Doman and Flentje (1970) ${ }^{[8]}$, Sherwood (1970) ${ }^{[28]}$.

\section{Evaluation of Aggressiveness of different isolates of Rizoctonia solani in pot condition}

The pot culture experiment was conducted with various $R$. solani isolates collected from different rice growing regions of Chhattisgarh to determine its aggressiveness on susceptible rice cultivar Swarna in kharif 2016 and kharif 2017. 
Highly aggressive isolates


$\sim 252 \sim$ 


\section{Aggressive isolates}
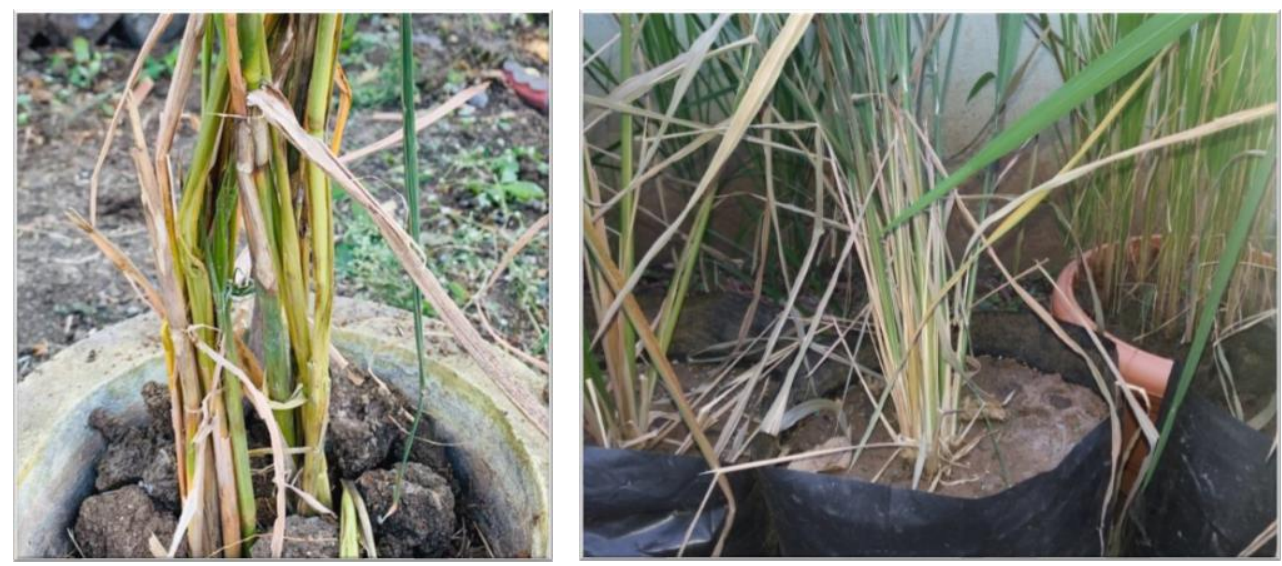

Moderately aggressive isolates

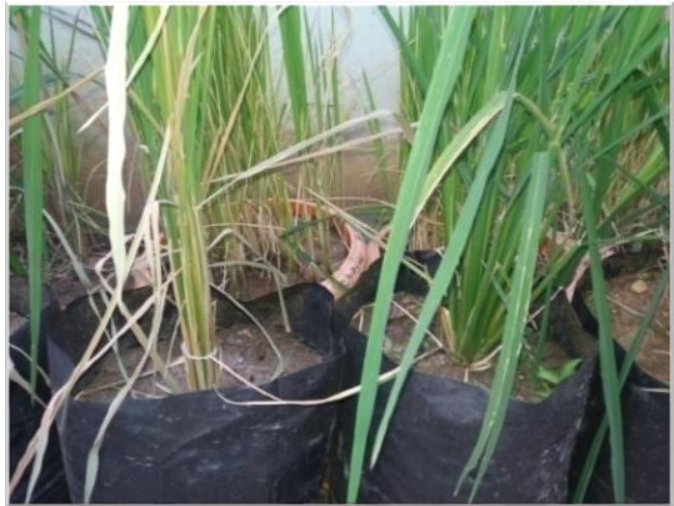

\section{Weakly aggressive isolate}
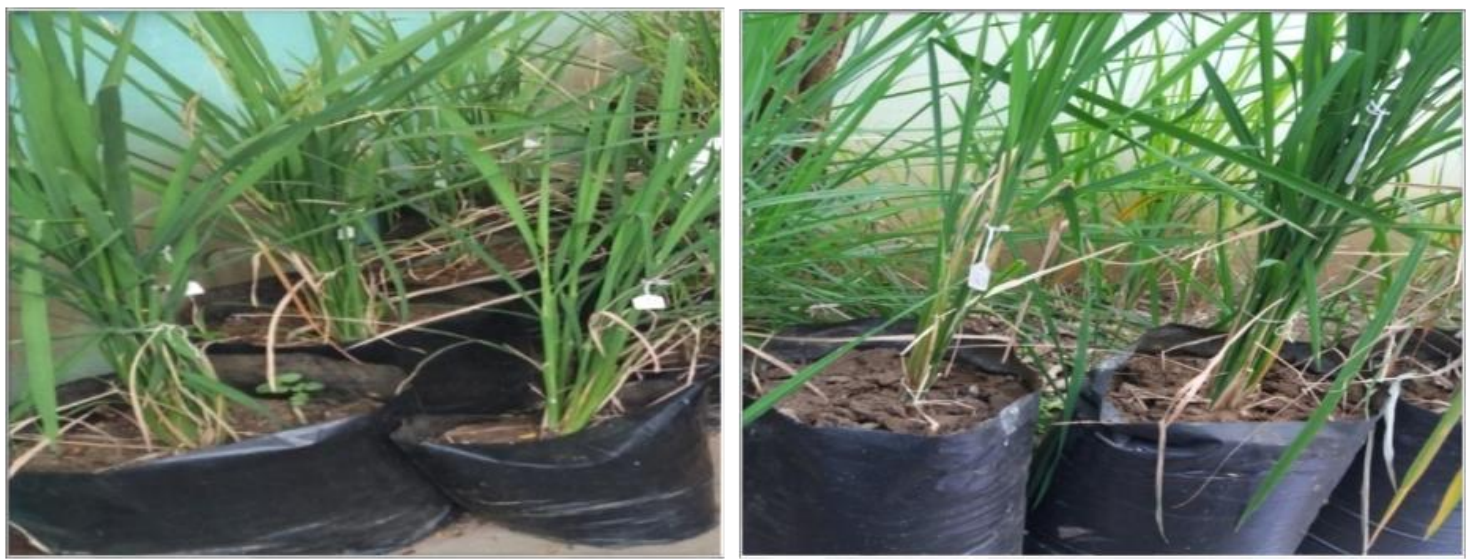

Fig 1.10: Aggressiveness test (pot condition) and variation in sheath blight disease symptoms

In kharif 2016, the data shown in table 1.4 and fig. 1.10 showed that the 58 isolates were divided into four groups: weakly aggressive (WA), moderately aggressive (MA), aggressive (A) and highly aggressive (HA). The majority of the isolates were weakly aggressive (21), followed by moderately aggressive (17), aggressive (12) and highly aggressive (8) against the susceptible Swarna variety of fiftyeight isolates. The results showed that the PDI was between $11.11 \%$ and $100 \%$ among all 58 isolates. The maximum PDI
(100\%) was recorded in isolate RS 3, followed by RS-57 (96.29\%), RS 4 (94.44\%) and RS-5 (92.59\%), while isolates RS8, RS9, RS 20, RS22, RS23, RS32, RS33, RS35, RS36, RS37, RS44, RS48, RS 49 and RS 55 showed the lowest PDI value (11.11). Reviewing the data showed significant differences in the aggressiveness of the isolates. The isolates showed varied incubation period, lesion lengths, relative lesion heights, disease severity and percent disease index. 
Table 1.3: Evaluation of Aggressiveness of different isolates of Rizoctonia solani under pot condition in kharif 2016

\begin{tabular}{|c|c|c|c|c|c|c|}
\hline \multirow{2}{*}{ Isolates } & \multirow{2}{*}{ Incubation period } & \multicolumn{3}{|c|}{ Lesion length (c.m.) } & \multirow{2}{*}{ Relative Lesion Height (cm) } & \multirow{2}{*}{ PDI (\%) } \\
\hline & & 1 week & 2 weeks & 3 weeks & & \\
\hline RS 1 & 1.41 & 10.35 & 16.81 & 22.24 & 51.22 & 72.21 \\
\hline RS 2 & 1.24 & 8.32 & 16.59 & 23.73 & 53.95 & 77.77 \\
\hline RS 3 & 1.08 & 15.60 & 26.71 & 36.61 & 81.30 & 100.0 \\
\hline RS 4 & 1.16 & 10.85 & 21.89 & 32.29 & 71.75 & 94.44 \\
\hline RS 5 & 1.16 & 15.46 & 22.66 & 30.65 & 71.31 & 92.59 \\
\hline RS 6 & 1.24 & 4.81 & 9.67 & 17.45 & 44.54 & 55.56 \\
\hline RS 7 & 1.0 & 4.66 & 7.77 & 12.30 & 32.16 & 37.18 \\
\hline RS 8 & 8.0 & 0.0 & 2.35 & 5.23 & 16.86 & 11.11 \\
\hline RS 9 & 4.25 & 1.24 & 3.44 & 4.90 & 15.15 & 11.11 \\
\hline RS 10 & 1.0 & 5.86 & 11.18 & 17.12 & 38.83 & 55.56 \\
\hline RS 11 & 1.24 & 2.54 & 6.65 & 9.81 & 22.69 & 16.66 \\
\hline RS 12 & 2.0 & 7.52 & 15.08 & 24.64 & 53.24 & 77.77 \\
\hline RS 13 & 1.0 & 4.51 & 8.43 & 13.18 & 29.70 & 35.18 \\
\hline RS 14 & 1.08 & 6.59 & 12.56 & 18.62 & 40.30 & 55.56 \\
\hline RS 15 & 1.24 & 5.71 & 11.73 & 18.92 & 40.64 & 55.56 \\
\hline RS 16 & 1.08 & 5.21 & 11.35 & 18.22 & 40.73 & 51.84 \\
\hline RS 17 & 1.25 & 4.86 & 10.70 & 17.46 & 37.73 & 53.69 \\
\hline RS 18 & 3.0 & 2.96 & 6.77 & 11.56 & 25.33 & 31.47 \\
\hline RS 19 & 1.58 & 4.41 & 9.16 & 19.01 & 39.74 & 51.84 \\
\hline RS 20 & 1.0 & 3.47 & 5.50 & 7.94 & 17.54 & 11.11 \\
\hline RS 21 & 2.25 & 3.07 & 5.95 & 8.45 & 18.68 & 25.92 \\
\hline RS 22 & 1.08 & 1.96 & 3.89 & 5.91 & 10.16 & 11.11 \\
\hline RS 23 & 5.0 & 0.19 & 1.63 & 3.28 & 9.72 & 11.11 \\
\hline RS 24 & 3.0 & 0.91 & 4.86 & 8.07 & 17.42 & 12.96 \\
\hline RS 25 & 1.16 & 7.89 & 12.34 & 18.29 & 37.67 & 53.69 \\
\hline RS 26 & 1.41 & 4.89 & 8.09 & 12.14 & 26.68 & 31.37 \\
\hline RS 27 & 1.0 & 4.48 & 7.25 & 11.47 & 24.89 & 33.33 \\
\hline RS 28 & 3.50 & 2.15 & 7.13 & 11.81 & 26.94 & 29.62 \\
\hline RS 29 & 1.75 & 3.38 & 7.36 & 11.52 & 25.80 & 24.07 \\
\hline RS 30 & 2.50 & 3.42 & 7.22 & 12.99 & 28.02 & 33.33 \\
\hline RS 31 & 1.16 & 3.99 & 6.65 & 9.65 & 21.12 & 18.51 \\
\hline \begin{tabular}{|l|} 
RS 32 \\
\end{tabular} & 4.66 & 0.37 & 2.69 & 4.08 & 10.57 & 11.11 \\
\hline RS 33 & 3.16 & 1.00 & 3.23 & 5.31 & 13.24 & 11.11 \\
\hline RS 34 & 1.0 & 11.83 & 20.35 & 29.35 & 59.90 & 80.55 \\
\hline RS 35 & 3.08 & 0.74 & 3.9 & 5.88 & 14.86 & 11.11 \\
\hline RS 36 & 4.58 & 0.26 & 2.21 & 3.59 & 10.37 & 11.11 \\
\hline RS 37 & 6.50 & 0.0 & 2.42 & 3.42 & 9.37 & 11.11 \\
\hline RS 38 & 3.08 & 2.06 & 4.23 & 6.51 & 15.83 & 12.96 \\
\hline RS 39 & 1.25 & 7.25 & 11.48 & 15.86 & 33.87 & 44.44 \\
\hline RS 40 & 1.0 & 4.25 & 8.41 & 12.87 & 28.33 & 33.33 \\
\hline RS 41 & 1.08 & 5.82 & 9.08 & 13.03 & 28.83 & 33.33 \\
\hline RS 42 & 1.24 & 4.78 & 8.40 & 11.93 & 25.84 & 33.33 \\
\hline RS 43 & 1.33 & 5.11 & 9.27 & 16.10 & 37.44 & 51.85 \\
\hline RS 44 & 3.50 & 0.96 & 1.91 & 2.87 & 8.74 & 11.11 \\
\hline RS 45 & 1.0 & 3.33 & 6.99 & 10.32 & 22.70 & 24.06 \\
\hline RS 46 & 3.33 & 1.58 & 4.62 & 6.79 & 16.41 & 16.67 \\
\hline RS 47 & 1.25 & 3.63 & 6.92 & 9.41 & 21.13 & 14.81 \\
\hline RS 48 & 3.25 & 1.69 & 4.54 & 6.98 & 16.64 & 11.11 \\
\hline RS 49 & 2.75 & 1.74 & 4.74 & 7.08 & 13.29 & 11.11 \\
\hline RS 50 & 1.0 & 9.74 & 16.68 & 24.02 & 45.54 & 61.11 \\
\hline RS 51 & 1.0 & 3.49 & 6.60 & 8.76 & 19.62 & 14.81 \\
\hline RS 52 & 1.33 & 3.95 & 7.26 & 10.97 & 24.75 & 29.62 \\
\hline RS 53 & 4.0 & 0.66 & 5.60 & 11.31 & 25.22 & 33.33 \\
\hline RS 54 & 1.25 & 3.03 & 5.96 & 10.06 & 22.63 & 22.21 \\
\hline RS 55 & 1.24 & 2.61 & 5.73 & 8.12 & 18.71 & 11.11 \\
\hline RS 56 & 3.24 & 2.22 & 7.21 & 9.36 & 22.66 & 20.36 \\
\hline RS 57 & 1.0 & 11.93 & 22.07 & 31.48 & 67.04 & 96.29 \\
\hline RS 58 & 1.08 & 4.92 & 11.08 & 17.22 & 39.93 & 57.39 \\
\hline Mean & 2.10 & 4.49 & 8.84 & 13.42 & 30.09 & 36.44 \\
\hline $\mathrm{CD}$ & & & & & 4.8283 & 8.1831 \\
\hline SEm & & & & & 1.7298 & 2.9317 \\
\hline
\end{tabular}

In Kharif 2017, the data shown in table 1.5 showed weak aggressiveness (WA), moderately aggressive (MA), aggressive (A) and high aggressiveness (HA) on susceptible variety Swarna. The majority of the isolates were weakly aggressive (25), followed by moderately aggressive (18), aggressive (9) and highly aggressive (6). The percent disease 
index was between $11.11 \%$ and $100 \%$. Among all 58 isolates, a maximum PDI of $100 \%$ was recorded in isolates RS 57, followed by RS 5 (92.59\%) and RS 3 (77.78\%), while isolates RS8, RS9, RS20, RS 21, RS22, RS23, RS24, RS 27 RS 31, RS32, RS33, RS35, RS36, RS37, RS38, RS44, RS45, RS46,
RS48, RS49 and RS51 showed the lowest PDI value (11.11). The isolates have different incubation period, lesion lengths, relative lesion heights, disease severity and percent disease index. The perusal of data showed significant differences in the aggressiveness of the isolates.

Table 1.4: Evaluation of Aggressiveness of different isolates of Rizoctonia solani under pot condition in kharif 2017

\begin{tabular}{|c|c|c|c|c|c|c|}
\hline \multirow{2}{*}{ Isolates } & \multirow{2}{*}{ Incubation period } & \multicolumn{3}{|c|}{ Lesion length (c.m.) } & \multirow{2}{*}{ Relative Lesion Height (cm) } & \multirow{2}{*}{ PDI (\%) } \\
\hline & & 1 week & 2 weeks & 3 weeks & & \\
\hline RS 1 & 1.24 & 9.40 & 15.79 & 23.56 & 53.36 & 70.37 \\
\hline RS 2 & 1.08 & 6.64 & 13.97 & 25.31 & 51.32 & 72.22 \\
\hline RS 3 & 1.16 & 11.12 & 19.63 & 26.62 & 56.63 & 77.78 \\
\hline RS 4 & 1.0 & 9.30 & 15.31 & 21.38 & 46.62 & 55.56 \\
\hline RS 5 & 1.24 & 14.26 & 23.42 & 33.20 & 68.67 & 92.59 \\
\hline RS 6 & 1.0 & 7.56 & 13.76 & 19.04 & 41.94 & 55.56 \\
\hline RS 7 & 1.24 & 6.41 & 9.32 & 13.04 & 29.06 & 33.33 \\
\hline RS 8 & 1.08 & 3.40 & 5.59 & 7.06 & 17.60 & 11.11 \\
\hline RS 9 & 2.83 & 0.96 & 2.89 & 5.47 & 13.59 & 11.11 \\
\hline RS 10 & 1.0 & 8.13 & 11.85 & 16.34 & 35.33 & 50.0 \\
\hline RS 11 & 1.91 & 2.00 & 5.54 & 9.65 & 22.69 & 14.81 \\
\hline RS 12 & 1.16 & 4.42 & 8.19 & 14.19 & 31.31 & 35.18 \\
\hline RS 13 & 1.41 & 4.31 & 9.24 & 13.48 & 29.61 & 33.33 \\
\hline RS 14 & 1.0 & 6.42 & 11.33 & 16.98 & 36.02 & 50.0 \\
\hline RS 15 & 1.24 & 6.72 & 12.44 & 19.57 & 41.65 & 55.56 \\
\hline RS 16 & 1.49 & 5.33 & 9.70 & 14.58 & 32.28 & 40.74 \\
\hline RS 17 & 1.08 & 4.54 & 8.31 & 14.37 & 31.43 & 35.18 \\
\hline RS 18 & 1.83 & 4.99 & 7.63 & 14.53 & 32.13 & 38.88 \\
\hline RS 19 & 1.0 & 6.41 & 11.44 & 18.38 & 39.38 & 55.56 \\
\hline RS 20 & 1.0 & 4.15 & 6.56 & 7.52 & 17.11 & 11.11 \\
\hline RS 21 & 1.08 & 2.25 & 4.56 & 6.79 & 17.08 & 11.11 \\
\hline RS 22 & 1.50 & 2.83 & 4.76 & 6.85 & 17.60 & 11.11 \\
\hline RS 23 & 1.0 & 1.76 & 3.36 & 4.63 & 13.26 & 11.11 \\
\hline RS 24 & 2.0 & 2.56 & 5.62 & 7.98 & 18.81 & 11.11 \\
\hline RS 25 & 1.24 & 9.27 & 13.38 & 18.44 & 39.00 & 55.56 \\
\hline RS 26 & 1.0 & 4.11 & 8.26 & 12.51 & 27.13 & 33.33 \\
\hline RS 27 & 1.25 & 3.13 & 6.30 & 8.58 & 19.51 & 11.11 \\
\hline RS 28 & 1.24 & 4.47 & 8.16 & 11.42 & 24.63 & 31.47 \\
\hline RS 29 & 1.75 & 4.36 & 7.20 & 9.78 & 21.70 & 20.36 \\
\hline RS 30 & 1.25 & 6.30 & 10.01 & 12.81 & 29.92 & 35.18 \\
\hline RS 31 & 2.0 & 2.56 & 5.63 & 8.50 & 21.70 & 11.11 \\
\hline RS 32 & 1.0 & 2.31 & 3.69 & 4.73 & 15.23 & 11.11 \\
\hline RS 33 & 4.50 & 1.16 & 3.67 & 6.09 & 16.71 & 11.11 \\
\hline RS 34 & 2.08 & 4.95 & 9.27 & 16.89 & 37.57 & 51.85 \\
\hline RS 35 & 1.0 & 3.12 & 5.79 & 8.53 & 20.48 & 11.11 \\
\hline RS 36 & 2.14 & 2.07 & 3.09 & 3.55 & 11.71 & 11.11 \\
\hline RS 37 & 3.0 & 1.06 & 2.02 & 3.68 & 12.74 & 11.11 \\
\hline RS 38 & 2.25 & 2.16 & 4.38 & 6.25 & 17.08 & 11.11 \\
\hline RS 39 & 1.0 & 5.74 & 8.05 & 13.09 & 30.38 & 33.33 \\
\hline RS 40 & 1.24 & 5.44 & 10.97 & 14.73 & 32.78 & 40.74 \\
\hline RS 41 & 1.0 & 5.50 & 10.43 & 15.12 & 34.96 & 40.74 \\
\hline RS 42 & 1.25 & 4.82 & 8.27 & 11.72 & 26.91 & 29.62 \\
\hline RS 43 & 1.25 & 5.79 & 11.32 & 16.42 & 33.51 & 38.88 \\
\hline RS 44 & 3.0 & 1.05 & 2.41 & 3.32 & 10.58 & 11.11 \\
\hline RS 45 & 4.75 & 1.96 & 4.15 & 8.72 & 21.57 & 11.11 \\
\hline RS 46 & 1.75 & 2.70 & 5.26 & 7.46 & 19.54 & 11.11 \\
\hline RS 47 & 1.0 & 3.57 & 7.55 & 11.31 & 26.21 & 33.33 \\
\hline RS 48 & 1.50 & 2.96 & 5.13 & 6.79 & 17.90 & 11.11 \\
\hline RS 49 & 1.08 & 1.21 & 3.28 & 6.13 & 17.22 & 11.11 \\
\hline RS 50 & 1.08 & 7.53 & 13.87 & 21.67 & 44.21 & 66.67 \\
\hline RS 51 & 1.0 & 4.26 & 5.83 & 8.70 & 19.81 & 11.11 \\
\hline RS 52 & 1.0 & 3.38 & 6.93 & 10.33 & 24.45 & 20.36 \\
\hline RS 53 & 1.0 & 4.36 & 8.86 & 13.17 & 31.85 & 33.33 \\
\hline RS 54 & 2.08 & 4.11 & 7.60 & 11.18 & 26.25 & 27.77 \\
\hline RS 55 & 3.16 & 2.92 & 8.15 & 11.07 & 26.41 & 33.33 \\
\hline RS 56 & 1.16 & 3.04 & 6.16 & 9.15 & 22.21 & 12.96 \\
\hline RS 57 & 1.08 & 15.53 & 27.70 & 35.54 & 72.17 & 100.00 \\
\hline RS 58 & 1.08 & 6.28 & 11.81 & 17.06 & 39.29 & 55.56 \\
\hline Mean & 1.53 & 4.81 & 8.70 & 12.84 & 29.10 & 32.66 \\
\hline
\end{tabular}




\begin{tabular}{|c|l|l|l|l|l|l|}
\hline CD & & & & & 3.5057 & 6.9671 \\
\hline SEm & & & & & 1.2560 & 2.4961 \\
\hline
\end{tabular}

The pooled kharif data for 2016 and 2017 are listed in table 1.6. The aggressiveness quality (Fig. 4.12) was divided into the following four categories: weakly aggressive (WA = PDI\% 2-21), moderately aggressive (MA = PDI\% 22-43), aggressive $(\mathrm{A}=\mathrm{PDI} \%$ 44-65) $)$ and highly aggressive (HA=PDI percent 66-87) with a susceptible Swarna variety. The result showed that among the fifty-eight isolates, twenty two weakly aggressive isolates (RS8, RS9, RS11, RS20, RS21, RS22, RS23, RS24, RS31, RS32, RS33, RS35, RS36, RS37, RS38, RS44, RS45, RS46, RS48, RS49, RS51 and RS56) followed by seventeen moderately aggressive isolates (RS7, RS13, RS18, RS26, RS27, RS28, RS29, RS30, RS39, RS40, RS41, RS42, RS47, RS52, RS53, RS54 and RS55), twelve aggressive isolates (RS6, RS10, RS12, RS14, RS15, RS16, RS17, RS19, RS25, RS43, RS50 and RS58) and seven highly aggressive isolates (RS1, RS2, RS3, RS4, RS5, RS34 and RS57). The PDI of the isolates was between (11.11 $98.15 \%$ ). All isolates were found to be aggressive to rice and could develop lesions on leaves, leaf sheaths and susceptible stems of rice. The results showed that significant differences were found in the aggressiveness of isolates. The isolates varied depending on the lesion height, incubation period, relative lesion height, severity of the disease and percent disease index.

Of all 58 isolates, a maximum PDI of 98.15 percent was shown with RS57 isolate, followed by RS 5 (92.59 percent) and RS 3 (88.89 percent), while RS8, RS9, RS20, RS22, RS23, RS32, RS33, RS 35, RS36, RS37, RS44, RS48 and RS 49 isolates showed the lowest PDI value (11.11). The incubation period was between 1.0 and 4.75 days. The minimum incubation time (1.0 days), indicated by RS10, RS20 and RS51 isolates, and the maximum incubation time (4.75 days), indicated by RS37 isolate. The RS5 isolate (69.99 $\mathrm{cm}$ ) showed the highest relative lesion height, while the RS44 $(9.66 \mathrm{~cm})$ showed the lowest. The results of a pooled data analysis showed the isolates of $R$. solani were variable. These results are in agreement with the results of Madhavi et al. (2012) ${ }^{[17]}$ and Jayaprakashvel and Mathivanan (2011) ${ }^{[13]}$. Adhipathi et al. (2013) [1], Pavani et al. (2018) ${ }^{[23]}$, Singh et al. (2001) ${ }^{[30]}$ and Kumar et al. (2008) ${ }^{[15]}$ reported similar observations.

Table 1.5: Evaluation of Aggressiveness of different isolates of Rizoctonia solani under pot condition (Pooled data of year 2016 and 2017)

\begin{tabular}{|c|c|c|c|c|c|c|}
\hline \multirow{2}{*}{ Isolates } & \multirow{2}{*}{ Incubation period } & \multicolumn{3}{|c|}{ Lesion length (c.m.) } & \multirow{2}{*}{ Relative Lesion Height (cm) } & \multirow{2}{*}{ PDI (\%) } \\
\hline & & 1 week & 2 weeks & 3 weeks & & \\
\hline RS 1 & 1.33 & 9.88 & 16.30 & 22.89 & 52.29 & 71.29 \\
\hline RS 2 & 1.16 & 7.48 & 15.28 & 24.52 & 52.63 & 75.00 \\
\hline RS 3 & 1.12 & 13.36 & 23.17 & 31.62 & 68.97 & 88.89 \\
\hline RS 4 & 1.08 & 10.08 & 18.60 & 26.84 & 59.19 & 75.00 \\
\hline RS 5 & 1.20 & 14.86 & 23.04 & 31.93 & 69.99 & 92.59 \\
\hline RS 6 & 1.12 & 6.19 & 11.72 & 18.25 & 43.24 & 55.56 \\
\hline RS 7 & 1.12 & 5.54 & 8.55 & 12.67 & 30.61 & 35.26 \\
\hline RS 8 & 4.54 & 1.70 & 3.97 & 6.15 & 17.23 & 11.11 \\
\hline RS 9 & 3.54 & 1.10 & 3.17 & 5.19 & 14.37 & 11.11 \\
\hline RS 10 & 1.00 & 7.00 & 11.52 & 16.73 & 37.08 & 52.78 \\
\hline RS 11 & 1.58 & 2.27 & 6.10 & 9.73 & 22.69 & 15.74 \\
\hline RS 12 & 1.58 & 5.97 & 11.64 & 19.42 & 42.28 & 56.48 \\
\hline RS 13 & 1.21 & 4.41 & 8.84 & 13.33 & 29.66 & 34.26 \\
\hline RS 14 & 1.04 & 6.51 & 11.95 & 17.80 & 38.16 & 52.78 \\
\hline RS 15 & 1.24 & 6.22 & 12.09 & 19.25 & 41.15 & 55.56 \\
\hline RS 16 & 1.29 & 5.27 & 10.53 & 16.40 & 36.51 & 46.29 \\
\hline RS 17 & 1.17 & 4.70 & 9.51 & 15.92 & 34.58 & 44.44 \\
\hline RS 18 & 2.42 & 3.98 & 7.20 & 13.05 & 28.73 & 35.18 \\
\hline RS 19 & 1.29 & 5.41 & 10.30 & 18.70 & 39.56 & 53.70 \\
\hline RS 20 & 1.00 & 3.81 & 6.03 & 7.73 & 17.33 & 11.11 \\
\hline RS 21 & 1.67 & 2.66 & 5.26 & 7.62 & 17.88 & 18.52 \\
\hline RS 22 & 1.29 & 2.40 & 4.33 & 6.38 & 13.88 & 11.11 \\
\hline RS 23 & 3.00 & 0.98 & 2.50 & 3.96 & 11.49 & 11.11 \\
\hline RS 24 & 2.50 & 1.74 & 5.24 & 8.03 & 18.12 & 12.04 \\
\hline RS 25 & 1.20 & 8.58 & 12.86 & 18.37 & 38.34 & 54.63 \\
\hline RS 26 & 1.21 & 4.50 & 8.18 & 12.33 & 26.91 & 32.35 \\
\hline RS 27 & 1.13 & 3.81 & 6.78 & 10.03 & 22.20 & 22.22 \\
\hline RS 28 & 2.37 & 3.31 & 7.65 & 11.62 & 25.79 & 30.55 \\
\hline RS 29 & 1.75 & 3.87 & 7.28 & 10.65 & 23.75 & 22.22 \\
\hline RS 30 & 1.88 & 4.86 & 8.62 & 12.90 & 28.97 & 34.26 \\
\hline RS 31 & 1.58 & 3.28 & 6.14 & 9.08 & 21.41 & 14.81 \\
\hline RS 32 & 2.83 & 1.34 & 3.19 & 4.41 & 12.90 & 11.11 \\
\hline RS 33 & 3.83 & 1.08 & 3.45 & 5.70 & 14.98 & 11.11 \\
\hline RS 34 & 1.54 & 8.39 & 14.81 & 23.12 & 48.74 & 66.20 \\
\hline RS 35 & 2.04 & 1.93 & 4.85 & 7.21 & 17.67 & 11.11 \\
\hline RS 36 & 3.36 & 1.17 & 2.65 & 3.57 & 11.04 & 11.11 \\
\hline RS 37 & 4.75 & 0.53 & 2.22 & 3.55 & 11.06 & 11.11 \\
\hline RS 38 & 2.67 & 2.11 & 4.31 & 6.38 & 16.46 & 12.04 \\
\hline RS 39 & 1.13 & 6.50 & 9.77 & 14.48 & 32.13 & 38.89 \\
\hline
\end{tabular}




\begin{tabular}{|c|c|c|c|c|c|c|}
\hline RS 40 & 1.12 & 4.85 & 9.69 & 13.80 & 30.56 & 37.04 \\
\hline RS 41 & 1.04 & 5.66 & 9.76 & 14.08 & 31.90 & 37.04 \\
\hline RS 42 & 1.25 & 4.80 & 8.34 & 11.83 & 26.38 & 31.48 \\
\hline RS 43 & 1.29 & 5.45 & 10.30 & 16.26 & 35.48 & 45.37 \\
\hline RS 44 & 3.25 & 1.01 & 2.16 & 3.10 & 9.66 & 11.11 \\
\hline RS 45 & 2.88 & 2.65 & 5.57 & 9.52 & 22.14 & 17.59 \\
\hline RS 46 & 2.54 & 2.14 & 4.94 & 7.13 & 17.98 & 13.89 \\
\hline RS 47 & 1.13 & 3.60 & 7.24 & 10.36 & 23.67 & 24.07 \\
\hline RS 48 & 2.38 & 2.33 & 4.84 & 6.89 & 17.27 & 11.11 \\
\hline RS 49 & 1.92 & 1.48 & 4.01 & 6.61 & 15.26 & 11.11 \\
\hline RS 50 & 1.04 & 8.64 & 15.28 & 22.85 & 44.88 & 63.89 \\
\hline RS 51 & 1.00 & 3.88 & 6.22 & 8.73 & 19.71 & 12.96 \\
\hline RS 52 & 1.17 & 3.67 & 7.10 & 10.65 & 24.60 & 24.99 \\
\hline RS 53 & 2.50 & 2.51 & 7.23 & 12.24 & 28.54 & 24.33 \\
\hline RS 54 & 1.67 & 3.57 & 6.78 & 10.62 & 24.44 & 22.99 \\
\hline RS 55 & 2.20 & 2.77 & 6.94 & 9.60 & 22.56 & 16.66 \\
\hline RS 56 & 2.20 & 2.63 & 6.69 & 9.26 & 22.44 & 98.15 \\
\hline RS 57 & 1.04 & 13.73 & 24.89 & 33.51 & 69.61 & 56.48 \\
\hline RS 58 & 1.08 & 5.60 & 11.45 & 17.14 & 39.61 & 34.55 \\
\hline Mean & 1.82 & 4.65 & 8.78 & 13.13 & 29.60 & 5.3383 \\
\hline CD & & & & & 2.9093 & 1.9125 \\
\hline SEm & & & & & 1.0423 & \\
\hline
\end{tabular}

The result showed that among fifty eight isolates, most of the isolates i.e. twenty two isolates were categorized as weakly aggressive, seventeen isolates were moderately aggressive, twelve isolates were aggressive and seven isolates were found highly aggressive. The PDI of the isolates was ranged between $11.11-98.15 \%$, a maximum PDI of 98.15 percent was shown with RS57 isolate.

\section{References}

1. Adhipathi P, Singh V, Meena SC. Virulence diversity of Rhizoctonia solani causing sheath blight disease in rice and its host pathogen interaction. The Bioscan. 2013; 8(3):949-952.

2. Anonymous. Rice Disease Survey. Rice Pathology News Letter. IRRI, Los Banos, Philippines. 1975; 1/75:8.

3. Anonymous. Sheath blight: Losses cost \$ 67 million a year. Rice J. 1988; 41:5-8.

4. Anonymous. Progress Report. India Council of Agricultural Research, New Delhi. 1971; 3:1-7.

5. Chaijuckam P, Baek JM, Greer CA, Webster RK, Davis RM. Population structure of Rhizoctonia Oryzae-sativae in California rice fields. Phytopath. 2010; 100:502-510.

6. Das NP. Resistance of some improved varieties of rice (Oryza sativa L.) to sheath blight caused by Rhizoctonia solani Kuhn. Indian J Agric. Sci. 1970; 40:566-568.

7. Dasgupta MK. Rice sheath blight: The challenge continues in: Plant Diseases of Int. Importance: Diseases of cereals and pulses. New India Publishing Agency. 1992, 115 pp.

8. Dodman RL, Flentje NT. The mechanism \& Physiology of Plant penetration by Rhizoctonia solani In: Parmeter J R (ed) Rhizoctonia solani, Biology \& Pathology. University of California Press, Berkeley, 1970, 149-160.

9. Goff SA. Rice as a modle for ceral genomics. Curr. Opin. Plant Biol. 1999; 2:86-89.

10. Guttierez WA, Shew HD, Melton TA. Sources of inoculum and management of Rhizoctonia solani damping-off on tobacco transplants undergreenh ouse conditions. Pl. Dis. 1997; 81:604-606.

11. Hori M. On forecasting the damage due to sheath blight of rice plants and the critical point for judging the necessity of chemical control of disease. Rev. Pl. Prot. Res. Tokyo. 1969; 2:70-73.
12. IRRI. The Int. Rice Testing program (The Int. Rice Research Institute) Los Banos, Laguna, Phillipinnes, 2014.

13. Jayaprakashvel M, Mathivanan N. Morphological and pathological variations of rice sheath blight inciting south Indian Rhizoctonia solani isolates. Archives of Phytopath. and Plant Protec. 2012, 455-467 pp.

14. Kipsumbai, Pixley Kiptui. Population dynamics and pathogenic behaviour of Rhizoctonia solani Kühn in response to rice based cropping system of Punjab. M.Sc. (Ag.) thesis, Panjab Agricultural University, 2015.

15. Kumar M, Singh V, Singh KN, Vikram P. Morphological and virulence characterization of Rhizoctonia solani causing sheath blight of rice. Environ. and Ecology. 2008; 26(3):1158-1166.

16. Lee FN, Rush MC. Rice sheath blight: A major rice disease. Pl. Dis. 1983; 67:829-832.

17. Madhavi M, Reddy PN, Reddy RR, Sudarshan MR. Evaluation of maize genotypes against banded leaf. and sheath blight disease incited by Rhizoctonia solani f.sp.sasakii (Khun) Exner. J of Res. ANGRAU. 2012; 40(4):20-23.

18. Matsumoto M. A qualitative baiting technique for selective isolation and DNA diagnosis of Rhizoctonia spp., causal agents of rice sheath diseases. Soil J Fac Agr Kyushu Univ. 2003; 48:13-20.

19. Miyake I. Studies uber die Pilze der Reispflanzen in Japan. J Coll. Agric. Tokyo. 1910; 2:237-276.

20. Mizuta $\mathrm{H}$. On the relation between yield and inoculation times of sheath blight Corticium sasakii in the earlier planted paddy rice. Ass. Pl. Prot. Kyashu. 1956; 2:100102.

21. Ou SH. Rice diseases. Commonwealth Mycological Institute. Kew, Survey, England, 1972, 368.

22. Parmeter JR, Whitney HS. Taxonomy and nomenclature of the imperfect state- Rhizoctonia solani. In: (Ed. J.R. Parmeter). Biology and Pathology. University of California Press, Berkley University of California Press, Berkelay, Los Angeles and London, 1970.

23. Pavani Lalitha S, Singh Vineeta. Assessment of Virulence Diversity of Rhizoctonia solani Causing Sheath Blight Disease in Rice from Eastern Up. Current J 
of Applied Science and Technology. 2018; 26(6):1-10. Article no. CJAST. 41052.

24. Prasad VR. Integrated management of sheath blight disease of rice. M.Sc. (Ag.) thesis, Department of Plant Pathology College of Horticulture, Vellanikkara, Thrissur, Kerala, India, 2014.

25. Rajan CPD, Naidu VD. Sheath blight damage to seven rices. Int. Rice. Res. Newsl. 1986; 11(1):6.

26. Saxena SC, Agnihotri VP, Sarbhoy AK, Singh DV. Banded leaf and sheath blight of maize. In: Management of threatening plant diseases of National importance. Malhotra publishing house, New Delhi. 1997, 31-50.

27. Sharma L, Goswami S, Nagrale DT. Culture and physiological variability in Rhizoctonia solani, responsible for foliar and lesions on aerial part of soybean. J of Applied and Natural Sci. 2013; 5(1):41-46.

28. Sherwood RT. Physiology of Rhizoctonia solani. In: Rhizoctonia solani. Biology and Pathology. University of California Press. Berkeley, 1970, 69-92.

29. Shimamoto K. The molecular biology of rice. Science. 1995; 270:172-173.

30. Singh A, Rohila R, Singh US, Savary S, Willocquel L, Duvoillor E. An improved inoculation technique for sheath blight of rice caused by Rhizoctonia solani. Canadian J Plant Pathology. 2001; 24:65-68.

31. Sneh B, Jabaji-Hare S, Neate S, Dijst G. Rhizoctonia species: taxonomy, molecular, biology, ecology, pathology and disease control. Dordrecht (The Netherlands): Kluwer Academic Publishers, 1996, 331340.

32. Sriram S, Raguchander $T$, Vidhyasekaran $P$, Muthukrishnan S, Samiyappan R. Genetic relatedness with special reference to virulence among the isolates of Rhizoctonia solani causing sheath blight in rice. Zeitschrift fur Pflanzenkrankheiten und Pflanzenschutz. 1997; 104(3):260271.

33. Swain NC, Chhotray AK, Mahapatra SS. Pathogenic variability of Rhizoctonia solani causing sheath blight of rice and its management. Jour. of Pl. Prote. and Enr. 2005; 1:96-99.

34. Verma ML, Agrawal KC, Upadhyay AR, Patel RK. Observation on rice disease and insects in Madhya Pradesh, India. Int. Rice Res. Newsl. 1979; 4(1):11.

35. Vidhyasekaran P, Ponmalar TR, Samiyappan R, Velazhahan R, Vimala R, Ramanathan A et al. Hostspecific toxin production by Rhizoctonia solani, the rice sheath blight pathogen. Biochem cell Biol. 1997; 87:1258-1263.

36. Xiao Y, Liu M, Li G, Zhou E, Wang L, Tang J et al. Genetic diversity and pathogenicity variation in Rhizoctonia solani isolates from rice in Sichuan Province, China. Rice Sci. 2008; 15:137-144. 